The second report was from the Warner area. While we were stopped at the home of friends in Warner, our conversation eventually turned to the discovery of the Kangaroo Rat colony and to a discussion of how rare these animals were in Alberta. To our surprise the lady of the house stated that while she was working in the county office, a farmer had brought a strange looking animal into the office for identification. Apparently no one in the county office was able to identify it so they referred to some books for help. After a perusal of several books the only conclusion they could reach as to the identification of this animal was that it was a Kangaroo Rat. When we asked her where this animal had been picked up she was not sure but thought it was east of the town of Milk River.

With the publication of this note more reports may be forthcoming. If anyone knows of such a colony or of any sightings of Kangaroo Rats, the senior auchor would appreciate hearing from these people so that a more definite distribution pattern may be worked out for Alberta.

\section{LITERATURE CITED}

Anderson, R. M. 1946. Catalogue of Canadian mammals. Nat. Mus. Can., Bull. No. 102. Biol. Series 31. p. 131.

Nero, R. W., and R. W. Fyfe. 1956. Kangaroo rat colonies found. Blue Jay, 14:107-110.

Nero, R. W. 1958. Additional Pocket Mouse records. Blue Jay, 16: 176-179.

Soper, J. D. 1964. The mammals of Alberta. The Queen's Printer, Edmonton.

\title{
COMMENTS ON THE RANGE OF THE NORTHERN POCKET GOPHER IN ALBERTA
}

\section{by Michael Wilson, 196 Westover Drive, Calgary 5, Alberta}

J. Dewey Soper (1964. The mammals of Alberta. Hamly Press, Edmonton) defined the range of one race of the Northern Pocket Gopher, Thomomys talpoides talpoides (Richardson), in Alberta as follows: "Sporadically throughout the aspen grove belt west to a line running from about Westlock southward through Stony Plain, Pigeon Lake, Rocky Mountain House, Sundre, Morley, Elbow Falls, Maycroft and Twin Butte to Belly River, Waterton Park; east to about Nanton and Blackie..." For three years I have made casual investigations of the distribution of this rodent in order to supplement Soper's data. Pocket Gophers or their burrows have been found at a number of localities which add to our knowledge of its distribution.

A heavy infestation, as evident from numerous fresh burrows, was observed from Cochrane west past the Jumpingpound SuIphur Plant, and at least to a point on Highway 1a one mile west of the Ghost River crossing. This agrees with Soper's data, which indicated Morley to be the western boundary of the range at this point.

Burrows were noted as fairly common in the immediate area of the University of Calgary Environmental Sciences Station at Barrier Lake, Kananaskis Valley. Zoology students at the centre in 1966 observed one live specimen. An incomplete skull (University of Calgary, Archaeology Colls., No. OS-329) was found by me two and one-half feet down in a cutbank of the Kananaskis River just north of its confluence with Ribbon Creek, and some distance south of the University Centre. It appears that the species exists in open areas west of the Moose Mountain dome, and adjacent to the Rocky Mountain Front Ranges.

Wayne W. Smith (pers. comm., 1968) reported that Pocket Gopher burrows were present quite far up the Sheep River valley, suggesting that this valley may provide an opportunity for the animals to extend their range somewhat to the west.

Burrows were observed along Willow Creek valley at least as far west 
as a point five miles west of Willow Creek Provincial Park. Near this point, a skull was found buried four feet down in a cutbank. The cranium was badly damaged, but the associated mandibles were well preserved (University of Calgary, Archaeology Colls., No. OS-567).

Three fresh burrows were observed at the Oldman River Recreation Area, on the Coleman-Kananaskis Highway, west of the Livingstone Gap. Evidently they exist farther up the Oldman River valley than was previously supposed. Unlike the other observations, which occurred in Transition Zone forest,s to Prairies, this observation was made in a Canadian Zone coniferous forest, confirming Soper's suggestion that "fringes of the Cana. dian Zone" are occupied.

Abundant burrows were observed from five to 10 miles north of the border station at Carway, Alberta, along Highway 2. As this area falls into the void in Soper's map between the ranges of $T . t$ talpoides and T.t. andersoni, no subspecific assignment can be suggested. It would be interesting to determine whether or not the two ranges touch, or whether Soper's mapped void remains valid.

Pocket Gophers in western Alberta, presumably referable to the subspecies T.t. talpoides, evidently occupy a more complicated and extensive range than has been credited to them by Hall and Kelson (The mammals of North America. 1959. Ronald Press, N.Y.) or Soper (op. cit.). Areas along the Kananaskis Highway, including areas behind the Rocky Mountain Front Range, may harbour small, marginal populations of this rodent.

The questionable validity of sight records, burrows, and excavated skulls is acknowledged. However, this data may be of value to field zoologists presently working with this species. Soper and others have commented on the range dynamism and spotty distribution of Pocket Gophers. The present note serves to reinforce the statement.

\section{A FREAK MORTALITY OF MEADOW VOLES DUE TO HIGHWAY MAINTENANCE}

\section{by Gordon Koshinsky and Margaret Koshinsky, Saskatoon}

On April 19, 1969 an unusual mortality of Meadow Voles (Microtus pennsylvanicus) was encountered along Highway No. 11, three to four miles northwest of Kenaston. The animals had perished in an oil strip on the south shoulder of the highway. Consultation with Highways Department crew members doing repairs in the area revealed that the south lane had been oiled at about 7:00 p.m. the previous evening. Gravel had been applied immediately but a narrow oil strip, averaging $20-24$ inches wide and one-eighth inch or less deep, was left uncovered on the shoulder. The crews had observed the animals dead in this strip upon returning to work 12 hours later.
A count was made of dead animals along a measured mile which comprised most of the mortality area. One hundred and sixty-five individuals were encountered, or an average of one per 32 feet of roadway. Identity was established from a random sample of 10 animals pried from the oil and cleaned in gasoline. Four of the individuals so examined were males; six were females.

The uncultivated right-of-way at this point is approximately 55 feet wide on the north and about 240 feet wide on the south where the C.N. railway parallels the highway. Concentrations of dead voles varied considerably but showed no correlation with cover in this right-of-way. This cover 